\title{
Molybdenum and sulfur incorporation as oxyanion substitutional impurities in calcium carbonate minerals: a computational investigation
}

Article

Accepted Version

Creative Commons: Attribution-Noncommercial-No Derivative Works 4.0

Midgley, S. D., Taylor, J. O., Fleitmann, D. and Grau-Crespo, R. (2020) Molybdenum and sulfur incorporation as oxyanion substitutional impurities in calcium carbonate minerals: a computational investigation. Chemical Geology, 553. 119796. ISSN 0009-2541 doi:

https://doi.org/10.1016/j.chemgeo.2020.119796 Available at https://centaur.reading.ac.uk/92282/

It is advisable to refer to the publisher's version if you intend to cite from the work. See Guidance on citing.

Published version at: https://doi.org/10.1016/j.chemgeo.2020.119796

To link to this article DOI: http://dx.doi.org/10.1016/j.chemgeo.2020.119796

Publisher: Elsevier

All outputs in CentAUR are protected by Intellectual Property Rights law, including copyright law. Copyright and IPR is retained by the creators or other copyright holders. Terms and conditions for use of this material are defined in the End User Agreement. 


\section{www.reading.ac.uk/centaur}

\section{CentAUR}

Central Archive at the University of Reading

Reading's research outputs online 


\title{
Molybdenum and sulfur incorporation as oxyanion substitutional impurities in calcium carbonate minerals: a computational investigation
}

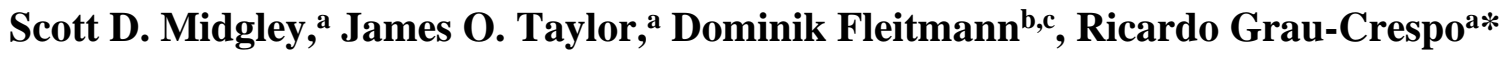 \\ ${ }^{a}$ Department of Chemistry, University of Reading, Whiteknights, Reading RG6 6AD, United Kingdom. \\ ${ }^{b}$ Department of Archaeology, University of Reading, Reading RG6 6AB, United Kingdom. \\ ${ }^{c}$ Department of Environmental Sciences, University of Basel, Bernoullistrasse 32, 4056 Basel, Switzerland. \\ *Email: r.grau-crespo@reading.ac.uk
}

Keywords: calcium carbonate; sulfate; molybdate; calcite; aragonite; vaterite; monohydrocalcite; ikaite

\begin{abstract}
Marked increases in sulfur and molybdenum concentration in stalagmites have been proposed as possible evidence of volcanic activity in the past. Thus, speleothems have great potential to deliver long and continuous records of volcanic activity. However, little is known about the chemical nature of these impurities in the calcium carbonate $\left(\mathrm{CaCO}_{3}\right)$ phases forming stalagmites, which hinders the rationalization of the incorporation mechanisms. While sulfur is known to incorporate as a sulfate anion in $\mathrm{CaCO}_{3}$ polymorphs, the nature and stability of molybdenum incorporation in these minerals has not been investigated yet. Here, we present a computer simulation study, based on density functional theory, comparing the thermodynamics of incorporation of sulfur and molybdenum as tetrahedral oxyanions $\left[\mathrm{XO}_{4}\right]^{2-}(\mathrm{X}=\mathrm{S}, \mathrm{Mo})$ in anion sites of $\mathrm{CaCO}_{3}$ polymorphs (calcite, aragonite, vaterite, monohydrocalcite and ikaite). Among the different polymorphs, vaterite incorporates $\left[\mathrm{XO}_{4}\right]^{2-}$ ions most favourably, which reflects the relatively low density of this carbonate phase. We show that molybdate anions are very unstable (more so than sulfate anions) in the bulk of all three anhydrous carbonate phases, with respect to the formation of naturally occurring competing phases. Most of the Mo impurities found in typical calcite/aragonite stalagmites is therefore likely to concentrate at surface/interface regions such as grain boundaries. Using the calcite (10.4) surface as a model, we show that the energies of substitution are indeed much lower at the surface than at the bulk. Our results suggest that factors affecting the crystallinity of $\mathrm{CaCO}_{3}$ in stalagmites, and therefore the specific surface area, will have a significant effect on the concentration of incorporated molybdenum, which should be a key consideration when interpreting data from Mo-based speleothem archives.
\end{abstract}




\section{Introduction}

Major volcanic eruptions have a strong effect on both the local and global climate. The cooling effect that follows large eruptions can in some cases last for decades after the actual eruption (Robock, 2000; Sigl et al., 2013; Zielinski, 2000). Much of our knowledge regarding the impact of volcanic eruptions on climate comes from paleo-volcanic records such as sulfate concentrations in ice cores (Severi et al., 2012; Yalcin et al., 2007; Zielinski et al., 1994), tree-rings (McCarroll and Loader, 2004) and marine and lake sediments (Lowe, 2011; Voelker, 2002). During the last decade, speleothems have been extensively studied as a new archive for paleo-volcanic activity (Badertscher et al., 2014; Fairchild and Treble, 2009; Finch et al., 2001; Ünal-İmer et al., 2015). This archive has been revealed to be a multiproxy source of information on climatic and environmental changes. Speleothem-based records such as trace element concentrations (Hartland et al., 2012), oxygen and carbon isotopes of calcite and hydrogen and oxygen isotopes of fluid inclusion water (Affolter et al., 2019; Fleitmann et al., 2009; Marshall et al., 2009) provide valuable information on decadal- to millennial-scale changes in precipitation and temperature. When compared to previous sources of paleo-volcanic activity data, speleothems have two important advantages. First, it is much easier to determine their absolute age accurately using uraniumseries dating (Dorale et al., 2004; St Pierre et al., 2009). Second, they can often be found in locations proximal to volcanoes (e.g. Badertscher et al., 2014). Comparatively, in ice cores, it is difficult to separate high and low latitudinal eruptions and therefore determine the location of the volcano.

Volcanic eruptions are often rich in elements (particularly sulfur) which will eventually become incorporated into speleothem calcite. In addition to sulfur, the concentrations of molybdenum and bromine in stalagmites have recently been identified as important tracers of volcanic activity (Badertscher et al., 2014). To rationalize the involved correlations, knowledge about atomic-level structural and thermodynamic aspects of the impurity incorporation is needed. Calcite, the most common polymorph of calcium carbonate, forms the majority of speleothems but given certain conditions, aragonite is also stable (De Choudens-Sanchez and Gonzalez, 2009; Given and Wilkinson, 1985; Railsback et al., 1994). Although much rarer, vaterite can also form when the temperature within the cave is low enough, or if specific ion concentrations are prevalent in the aqueous phase forming the solid, but it is known to be unstable with respect to recrystallization to calcite and/or aragonite (Lacelle et al., 2009). Monohydrocalcite $\mathrm{CaCO}_{3} \cdot \mathrm{H}_{2} \mathrm{O}$, (MHC), is a rare hydrous phase of calcium carbonate which has been discovered in cave environments in a few rare cases (Fischbeck and Müller, 1971; Stoffers and Fischbeck, 1974). Ikaite $\mathrm{CaCO}_{3} \cdot 6 \mathrm{H}_{2} \mathrm{O}$ is a hydrous phase of calcium carbonate commonly referred to as the "cold weather" phase. It is found in arctic environments, but is rare in caves. Field et al. (2018) reported the discovery of ikaite pseudomorphs in speleothems from the UK, which is the first evidence for ikaite being a constituent of speleothems. This rarity is partially because ikaite is known to be unstable with respect to recrystallisation at temperatures above $10^{\circ} \mathrm{C}$. Despite their rarity, the 
hydrated phases of calcium carbonate are still an important consideration in our investigation, due to the dynamic nature of calcium carbonate phase transformations over long timescales.

The chemistry of sulfur incorporation in calcium carbonates has been studied in previous work, for example: the isotopic ratios of sulfur in carbonates (Balan et al., 2014), sulfur incorporation as sulfate ions $\left(\mathrm{SO}_{4}\right)^{2-}$ in the bulk of different $\mathrm{CaCO}_{3}$ polymorphs (Fernández-Díaz et al., 2010), its effect on the growth of calcite (Vavouraki et al., 2008) and the reactions of $\mathrm{SO}_{2}$ with the calcite surface (Böke et al., 1999; Malaga-Starzec et al., 2004). It is clear from these studies that carbonate substitution by sulfate is increasingly unfavourable in the order vaterite - calcite - aragonite. In contrast, very little is known about the incorporation of molybdenum in carbonate minerals. By analogy with sulfur, one can assume that incorporation will occur by molybdate substitution at the carbonate site, but since the $\left(\mathrm{MoO}_{4}\right)^{2-}$ anion is bigger than the $\left(\mathrm{SO}_{4}\right)^{2-}$ anion, the energetics of the substitution can be expected to be quite different.

In this paper we discuss the incorporation of molybdate ions $\left(\mathrm{MoO}_{4}\right)^{2-}$ (and $\left(\mathrm{SO}_{4}\right)^{2-}$, for comparison) into $\mathrm{CaCO}_{3}$ polymorphs. We use quantum-mechanical simulations to elucidate the geometry and thermodynamics of incorporation of these anions in carbonate minerals: calcite, aragonite, vaterite, ikaite and monohydrocalcite (MHC).

\section{Computational Methods}

Calcium carbonates and their interactions with other phases have been widely studied using computer simulation methods based on classical interatomic potentials (e.g. de Leeuw and Parker, 1998; Raiteri et al., 2010; Ruiz-Hernandez et al., 2010; Wang et al., 2011). However, because in this and following work we want to study a range of impurities for which currently there are no interatomic potentials available, and to gain in accuracy, we have performed our calculations using quantum- mechanical methods based on the density functional theory (DFT), as implemented in the VASP code (Kresse and Furthmüller, 1996a; Kresse and Furthmüller, 1996b). The generalized gradient approximation (GGA) was used for the exchange-correlation term, with the functional by Perdew et al. (1996). The projector augmented wave (PAW) method (Blöchl, 1994; Kresse and Joubert, 1999) was used to describe the interactions between the cores (including electrons in orbitals up to $1 \mathrm{~s}$ for $\mathrm{C}$ and $\mathrm{O}, 2 \mathrm{p}$ for $\mathrm{Ca}$ and $\mathrm{S}$, and $3 \mathrm{~d}$ for Mo, which were frozen at the atomic reference states) and the valence electrons. The number of plane waves in the basis was determined by a kinetic energy cutoff of $520 \mathrm{eV}$, which is $30 \%$ above the recommended value for the set of PAW potentials used, to minimize Pulay stress errors.

We considered five different calcium carbonate phases. Calcite is trigonal with a space group of R-3C (167) (Markgraf and Reeder, 1985), and is modelled here using a hexagonal cell. Aragonite is orthorhombic with space group Pmcn (62) (De Villiers, 1971). Vaterite is an interesting case as there are several proposed models with different space groups. Its structure has been described using an 
orthorhombic crystal system with space groups Ama2 (40) and Pbnm (62) but also using a hexagonal crystal system with space groups $\mathrm{P}_{2} 2$ (179), $\mathrm{P}_{2} 21$ (154) or $\mathrm{P} 6_{3} / \mathrm{mmc}$ (194). We chose the hexagonal crystal system with space group P6522, as reported by Wang and Becker (2009), which has the advantage of being fully ordered (no fractional site occupancies). In this structure there are two possible positions for the carbon atom: $6 \mathrm{a}$ and $12 \mathrm{c}$, using the Wyckoff notation. Incorporation at both sites has been investigated. The experimental structure for MHC was reported by Swainson (2008) and is described using a trigonal crystal system with a $\mathrm{P} 3{ }_{1}$ (144) space group. It contains three inequivalent carbon positions, all possessing the same 3a Wyckoff symbol. We henceforth refer to these three unique positions as 3a1, 3a2 and 3a3. Finally, ikaite is monoclinic with space group C12/c1(15) (Hesse et al., 1983), with no non-standard structural features. Table 1 below shows that there is good agreement between the calculated and experimental unit cell parameters for each of the five phases studied.

Table 1. Relaxed cell parameters and symmetry notation for the unit cell of each polymorph in the bulk.

\begin{tabular}{lllllll}
\hline & & Calcite & Aragonite & Vaterite & MHC & Ikaite \\
\hline $\begin{array}{l}\text { Crystal } \\
\text { System }\end{array}$ & & $\begin{array}{l}\text { Hexagonal } \\
(\text { space group) }\end{array}$ & $\begin{array}{l}\text { Orthorhombic } \\
(\mathrm{Pmcn})\end{array}$ & $\begin{array}{l}\text { Hexagonal } \\
\left(\mathrm{P}_{2} 2\right)\end{array}$ & $\begin{array}{l}\text { Trigonal } \\
\left(\mathrm{P} 3_{1}\right)\end{array}$ & $\begin{array}{l}\text { Monoclinic } \\
(\mathrm{C} 12 / \mathrm{c} 1)\end{array}$ \\
$a / \AA$ & & & & & \\
& Calc & 5.049 & 5.011 & 7.290 & 10.632 & 8.839 \\
$b / \AA$ & Exp & 4.988 & 4.961 & 7.273 & 10.555 & 8.792 \\
& Calc & 5.049 & 8.019 & 7.290 & 10.632 & 8.313 \\
$c / \AA$ & Exp & 4.988 & 7.967 & 7.273 & 10.555 & 8.310 \\
& Calc & 17.218 & 5.800 & 25.450 & 7.640 & 10.953 \\
$\beta /{ }^{\circ}$ & Exp & 17.061 & 5.687 & 25.499 & 7.564 & 11.021 \\
& Calc & - & - & - & - & 108.6 \\
& Exp & - & - & - & - & 110.5 \\
\hline
\end{tabular}

When simulating the anion substitutions, supercells were used to minimize the interaction between an impurity and its periodically repeated image. A single $\left(\mathrm{CO}_{3}\right)^{2-}$ anion from each supercell was replaced with a tetrahedral $\left(\mathrm{XO}_{4}\right)^{2-}$ anion, similarly to previous work by Arroyo-de Dompablo et al. (2015) and Fernández-Díaz et al. (2010). The supercells we used were: $3 \times 3 \times 1$ for calcite $(54$ formula units of $\mathrm{CaCO}_{3}$ ), $3 \times 2 \times 3$ for aragonite ( 72 formula units), and $2 \times 2 \times 1$ for vaterite ( 72 formula units). For the hydrated calcium carbonate phases (MHC and ikaite), $2 \times 2 \times 2$ supercells were used, which led to cell sizes similar to those used for the anhydrous phases. As a preliminary investigation of surface incorporation behavior, we considered anion substitution in the calcite (10.4) plane, which is the dominant and most stable surface termination of calcite (de Leeuw and Parker, 1998; Rohl et al., 2003). 
The (10.4) surface was modelled using a slab consisting of 4 layers and a vacuum space of $12 \AA$; the bottom two layers were fixed to their bulk positions.

We characterize the stability of anion substitutions using two different measures. The first one is the ion exchange energy, $\Delta E_{\text {exch, }}$ which is the energy required to exchange a $\left(\mathrm{CO}_{3}\right)^{2-}$ anion with an $\left(\mathrm{XO}_{4}\right)^{2-}$ from the gas phase:

$$
\begin{gathered}
\mathrm{Ca}_{n}\left(\mathrm{CO}_{3}\right)_{n}+\left(\mathrm{XO}_{4}^{2-}\right)_{\text {gas }} \rightarrow \mathrm{Ca}_{n}\left(\mathrm{CO}_{3}\right)_{n-1} \mathrm{XO}_{4}+\left(\mathrm{CO}_{3}^{2-}\right)_{\text {gas }} \\
\Delta E_{\text {exch }}=E\left[\mathrm{Ca}_{n}\left(\mathrm{CO}_{3}\right)_{n-1} X \mathrm{O}_{4}\right]-E\left[\mathrm{Ca}_{n}\left(\mathrm{CO}_{3}\right)_{n}\right]+\left(E\left[\left(X \mathrm{O}_{4}^{2-}\right)_{\text {gas }}\right]-E\left[\left(\mathrm{CO}_{3}^{2-}\right)_{\text {gas }}\right]\right) .
\end{gathered}
$$

Here $E\left[\mathrm{Ca}_{n}\left(\mathrm{CO}_{3}\right)_{n-1} \mathrm{XO}_{4}\right]$ is the energy of the calcium carbonate supercell containing one $\left(\mathrm{XO}_{4}{ }^{2-}\right)$ anion in a carbonate site; $E\left[\mathrm{Ca}_{n}\left(\mathrm{CO}_{3}\right)_{n}\right]$ is the energy of the pure calcium carbonate supercell (or hydrated calcium carbonate in the case of MHC and ikaite); $E\left[\left(\mathrm{XO}_{4}{ }^{2-}\right)_{\mathrm{gas}}\right]$ and $E\left[\left(\mathrm{CO}_{3}{ }^{2-}\right)_{\mathrm{gas}}\right]$ are the energies of the isolated anions, which were obtained in a cell with a positive charge background to restore charge neutrality. Because the density of the background charge depends on the supercell size, the $E\left[\left(\mathrm{XO}_{4}{ }^{2-}\right)_{\text {gas }}\right]$ - $E\left[\left(\mathrm{CO}_{3}{ }^{2-}\right)_{\text {gas }}\right]$ term of Equation 1 was extrapolated to the limit of an infinite-size cell from calculations in supercells of increasing size (Figure 1). We use the gas phase (in the limit of isolated anions) as a reference state for computational convenience, and obviously not in connection with any relevant geochemical process. The purpose here is to use a common reference state to compare the stability of the substitution anions across different carbonate phases, including the hydrated ones. Only the relative values of $\Delta E_{\text {exch }}$ between different phases are relevant; the absolute values do not carry useful information.

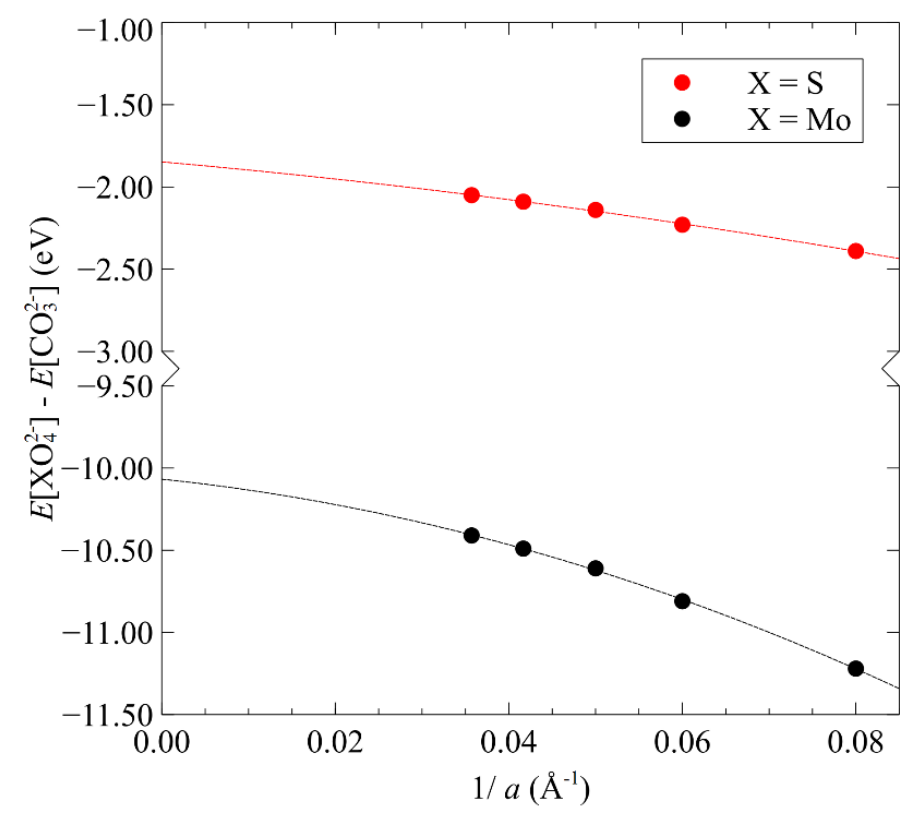

Figure 1. Variation of the energy difference $E\left[\mathrm{XO}_{4}{ }^{2-}\right]-E\left[\mathrm{CO}_{3}{ }^{2-}\right]$ with the inverse of the lattice parameter $a$, and extrapolations to the infinite cell using quadratic polynomials. 
The second measure used to evaluate the stability of substitution is the solution energy, $\Delta E_{\text {sol }}$, which is the energy of substituting the anion with reference to relevant competing phases $\left(\mathrm{CaXO} \mathrm{O}_{4}\right.$ solids):

$$
\begin{gathered}
\frac{(n-1)}{n} \mathrm{Ca}_{n}\left(\mathrm{CO}_{3}\right)_{n}+\mathrm{CaXO}_{4} \rightarrow \mathrm{Ca}_{n}\left(\mathrm{CO}_{3}\right)_{n-1} \mathrm{XO}_{4} \\
\Delta E_{\mathrm{sol}}=E\left[\mathrm{Ca}_{n}\left(\mathrm{CO}_{3}\right)_{n-1} \mathrm{XO}_{4}\right]-\frac{(n-1)}{n} E\left[\mathrm{Ca}_{n}\left(\mathrm{CO}_{3}\right)_{n}\right]-E\left[\mathrm{CaXO}_{4}\right]
\end{gathered}
$$

where $E\left[\mathrm{Ca}_{n}\left(\mathrm{CO}_{3}\right)_{n}\right]$ is the energy of the pure calcium carbonate supercell, and $E\left[\mathrm{CaXO} \mathrm{O}_{4}\right]$ is the energy per formula unit of the competing phase: powellite, $\mathrm{CaMoO}_{4}$, for molybdate substitutions, and anhydrous $\mathrm{CaSO}_{4}$ for sulfate substitutions. The $\Delta E_{\text {sol }}$ energies, which correspond to the solid solution mixing energies (per impurity atom) are not calculated for the hydrated phases, because the endmembers of the solid solutions exhibit different degrees of hydration. However, the absolute values of $\Delta E_{\text {sol }}$ provide some insight on the stability of the impurity incorporation with respect to the formation of competing phases, and therefore on how likely bulk substitution is in each phase.

\section{Results and Discussion}

The calculated ion exchange energies are shown in Table 2. For sulfate/carbonate substitutions in the anhydrous calcium carbonate polymorphs, the ion exchange energies follow the order vaterite < calcite $<$ aragonite, which is in agreement with previous work by (Arroyo-de Dompablo et al., 2015). This previous work did not consider the hydrated phases. Our calculations of the hydrated phases show that the sulfate/carbonate exchange energies for both MHC and ikaite are of similar values as for calcite. The lowest-energy substitution occurs in the low-density polymorph vaterite, in particular in the 12c sites, where sulfate/carbonate exchange is much more stable than in calcite by $\sim 0.8 \mathrm{eV}$. On the other side of the ranking, the ion exchange requires much more energy in the high-density polymorph aragonite $(2 \mathrm{eV}$ more than in vaterite $12 \mathrm{c}$ sites, and $1.3 \mathrm{eV}$ more than in calcite).

For molybdate/carbonate exchange, the trend is found to be like the one observed for sulfate/carbonate exchange, with the order vaterite < calcite < aragonite among the anhydrous phases, and the $12 \mathrm{c}$ site of vaterite being the most favourable. Substitution in calcite and aragonite is less stable than in vaterite (12c) by $1 \mathrm{eV}$ and $2.7 \mathrm{eV}$, respectively. In this case the exchange energies at the hydrated phases MHC and ikaite are intermediate between those at calcite and at aragonite, but closer to the former. Figure 2 provides a graphic illustration of the similarity between sulfate and molybdate exchange energies. There is an approximately linear correlation between the two sets of values. However, exchange energy differences between phases are larger (by $\sim 44 \%$ ) for molybdate than for 
sulfate substitution. This can be rationalised considering the larger size of the molybdate anion, which is therefore more difficult to accommodate in the smaller (and flat) carbonate sites, in hosts with higher density.

Table 2. Calculated ion exchange energies of substitution for sulfate and molybdate anions in different calcium carbonate phases.

\begin{tabular}{lcc}
\hline & \multicolumn{2}{c}{$\Delta E_{\text {exch }} / \mathrm{eV}$} \\
\cline { 2 - 3 } polymorph & sulfate & molybdate \\
\hline calcite & 1.15 & 1.45 \\
aragonite & 2.40 & 3.18 \\
vaterite $-6 \mathrm{a}$ & 0.68 & 1.10 \\
vaterite - 12c & 0.37 & 0.48 \\
MHC - 3a1 & 1.48 & 1.95 \\
MHC - 3a2 & 1.14 & 2.13 \\
MHC - 3a3 & 1.10 & 1.93 \\
ikaite & 1.28 & 2.01 \\
\hline
\end{tabular}

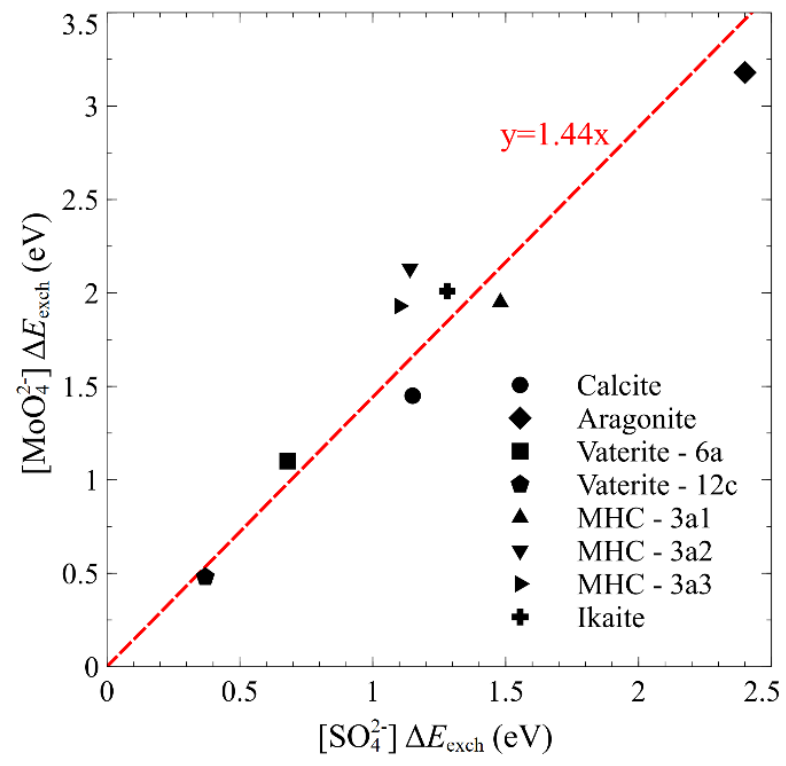

Figure 2. $\Delta E_{\text {exch }}$ energies of molybdate vs. sulfate substitutions in calcium carbonate phases.

The density of the host phase is clearly a key factor determining the relative substitution energies of large tetrahedral anions in the carbonate sites across calcium carbonate phases of the same composition. However, when including the hydrated phases in the comparison, trends cannot be 
established, because these phases have different chemical compositions and cannot be placed in the same density scale as the others. The densities of MHC and ikaite are much lower than those of the anhydrous phases because they have space occupied by lighter atoms. Therefore, the stability of the substitution must be rationalised in more general terms, for example, as function of the space available around the anion and the interactions with neighbouring atoms.

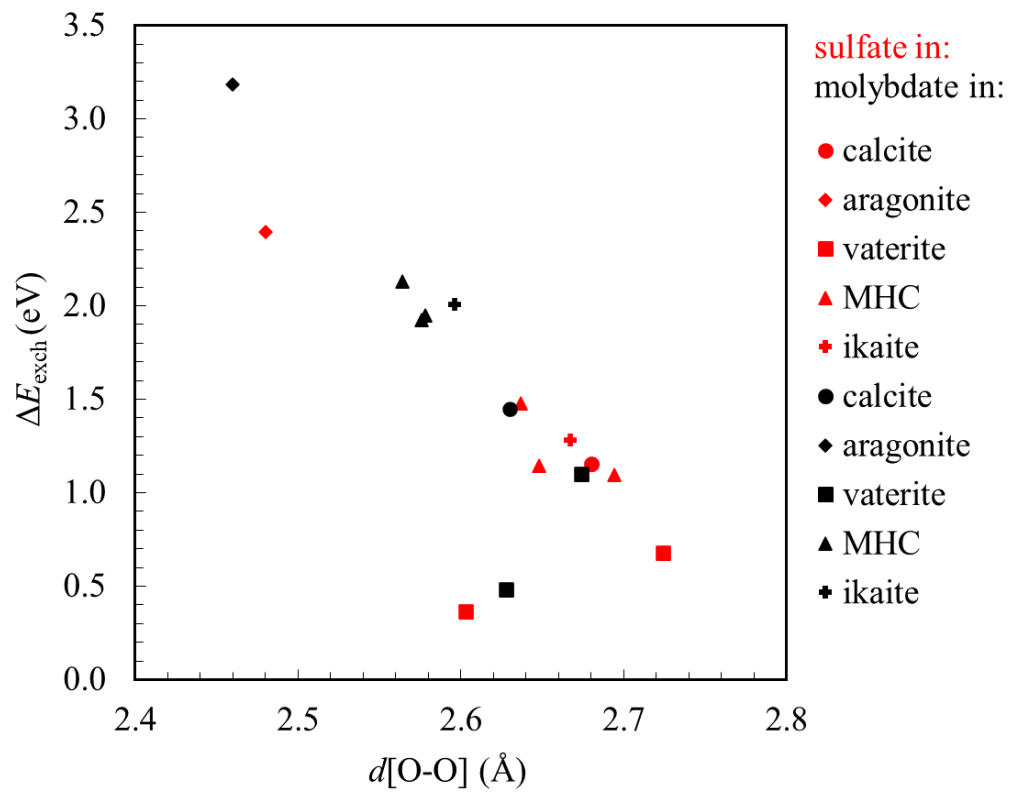

Figure 3. $\Delta E_{\text {exch }}$ energies of molybdate and sulfate substitutions in calcium carbonate phases versus the shortest distance from impurity oxygen to carbonate oxygen in the optimized structure.

In the Supplementary Information we visualize the geometric environments around each type of impurity in each of the carbonate phases, including the most relevant interatomic distances and angles (full crystal structures also available in CIF format). The most obvious pattern that emerges is the inverse correlation between the shortest distance from impurity oxygen to carbonate oxygen, and the energy cost of anion exchange (Figure 3). This makes sense on the basis that the energetic cost of the substitution mainly comes from accommodating the fourth oxygen in the tetrahedral ion, which suffers the strongest electrostatic repulsion from the carbonate oxygen atoms. In general, values for molybdate are shifted left with respect to the corresponding values for sulfate, indicating that it is more difficult for the molybdate impurity to escape the repulsion from the host carbonate anions. The plot in Figure 3 also rationalises the intermediate values of the exchange energies at the hydrated phases, for which a correlation with density cannot be established: the shortest impurity oxygen-carbonate oxygen distances for the hydrated phases are indeed intermediate between those of calcite and aragonite. The simple correlation in Figure 3 is, however, unable to account for the different behaviour of sites $6 \mathrm{a}$ and $12 \mathrm{c}$ of vaterite (the latter are the squares at around $2.6 \AA$, which are the obvious outliers in the trend). We have 
examined this case in more detail by calculating the electrostatic-only energy (using quantummechanically derived charges on the ions) but including not only the shortest $\mathrm{O}-\mathrm{O}$ distance but all the carbonate neighbours within a certain radius. Such analysis reveals that the preference for site $12 \mathrm{c}$ over $6 \mathrm{a}$ is still electrostatic in origin, it just requires the consideration of the full geometric environment around the impurity ions rather than just the shortest distance.

The exchange energies reported above are obtained with respect to an arbitrary (but convenient) reference state of the impurity ions. That allowed for comparison across polymorphic phases, but the absolute values do not contain any information on stability with respect to competing phases. The energies of incorporation of sulfate and molybdate into calcium carbonate was also calculated with respect to a competing solid phase (calcium sulfate or calcium molybdate), and the results are shown in Table 3.

Table 3. Solution energies $\left(\Delta E_{\mathrm{sol}}\right)$ and maximum equilibrium molar fraction $\left(x_{\mathrm{m}}\right)$ for $\mathrm{S}$ or Mo incorporation as oxyanions in calcium carbonate phases. The reference endmember phase is powellite $\mathrm{CaMoO}_{4}$ for molybdate and anhydrous $\mathrm{CaSO}_{4}$ for sulfate anions. For vaterite, $x_{\mathrm{m}}$ values are calculated assuming that only $12 \mathrm{c}$ sites are occupied.

\begin{tabular}{lcccc}
\hline & \multicolumn{2}{c}{$\Delta E_{\text {sol }} / \mathrm{eV}$} & \multicolumn{2}{c}{$x_{\mathrm{m}}=\exp \left(-\Delta E_{\text {sol }} / k_{\mathrm{B}} T\right)$} \\
polymorph & sulfate & molybdate & sulfate & molybdate \\
\hline calcite & 1.04 & 2.05 & $3 \times 10^{-18}$ & $4 \times 10^{-35}$ \\
aragonite & 2.41 & 3.91 & $3 \times 10^{-41}$ & $2 \times 10^{-66}$ \\
vaterite $-12 \mathrm{c}$ & 0.29 & 1.13 & $9 \times 10^{-6}$ & $7 \times 10^{-20}$ \\
vaterite $-6 \mathrm{a}$ & 0.60 & 1.76 & & \\
\hline
\end{tabular}

The positive $\Delta E_{\text {sol }}$ values indicate that for both sulfate and molybdate anions it is energetically preferable to form the competing phases rather than to incorporate as impurities in the bulk of calcium carbonate phases. At any temperature, a small amount of impurities can still be incorporated in thermodynamic equilibrium thanks to the configurational entropy contribution. However, the solution energies are so strongly positive that the maximum stable molar fraction $\left(x_{\mathrm{m}}\right)$ is extremely small. To illustrate this point, values for $x_{\mathrm{m}}$, assuming isolated substitutions in bulk, can be estimated from the minimum of the free energy:

$$
\Delta G=x \Delta E_{\mathrm{sol}}+k_{B} T\{x \ln (x)+(1-x) \ln (1-x)\}
$$


where $k_{\mathrm{B}}$ is Boltzmann's constant and $T$ is the temperature (we use ambient temperature of $300 \mathrm{~K}$ in our analysis). We ignore vibrational and pressure-volume effects here as they are typically much smaller contributions to the free energy. The minimum of the configurational free energy is at:

$$
x_{\mathrm{m}}=\frac{\exp \left(-\Delta E_{\mathrm{sol}} / k_{\mathrm{B}} T\right)}{1+\exp \left(-\Delta E_{\mathrm{sol}} / k_{\mathrm{B}} T\right)} \approx \exp \left(-\Delta E_{\mathrm{sol}} / k_{\mathrm{B}} T\right)
$$

and the values are shown in Table 3. Only in the case of sulfur impurities in vaterite, a significant level of substitution ( $\sim 9 \mathrm{ppm})$ is thermodynamically stable against separation into the competing phase. Values for molybdate substitutions are many orders of magnitude higher than for sulfate substitutions, reflecting the higher energetic cost of accommodating the larger molybdate anions in the calcium carbonate lattices.

Of course, actual sulfate incorporation in carbonate phases can be much higher than those obtained from the above analysis: they are in the parts per million for non-biogenic calcite and aragonite (Busenberg and Plummer, 1985) and in the parts per thousands in biogenic carbonates (Kampschulte et al., 2001). Our analysis show that sulfate incorporation by substituting carbonate anions in bulk lattice sites must account for a very small fraction of the total concentrations measured. Some level of metastable lattice substitution is possible, as sulfate impurities can enter the lattice from the solution from which the carbonate precipitates and become trapped there by kinetic barriers to diffusion, even if there is a thermodynamic preference to form a competing phase. But based on the calculated stabilities, we conclude that other incorporation pathways, including surface substitution/adsorption or stabilization via defects or other impurities in the bulk, should account for most of the detected sulfate ions in carbonates. In the case of molybdate, this conclusion is even stronger, because lattice $\left(\mathrm{MoO}_{4}\right)^{2-}$ $/\left(\mathrm{CO}_{3}\right)^{2-}$ substitutions at the bulk are prevented by a huge energy cost.

As an example of how much easier it would be to have sulfate or molybdate impurities at the surfaces than at the bulk of the carbonates, we have also calculated the energetic cost of $\left(\mathrm{XO}_{4}\right)^{2-} /\left(\mathrm{CO}_{3}\right)^{2-}$ substitutions at the (10.4) surface of calcite. In this case, the fourth oxygen in the tetrahedral anion can protrude from the surface, and therefore be accommodated farther from the repulsion of other oxygen species (Figure 4), leading to lower strain. The corresponding solution energies, i.e. the energetic costs of bringing the impurity anion from a competing phase to the surface, are $0.30 \mathrm{eV}$ for sulfate and 0.44 $\mathrm{eV}$ for molybdate, which are $20-30 \%$ of the bulk values. 
a)

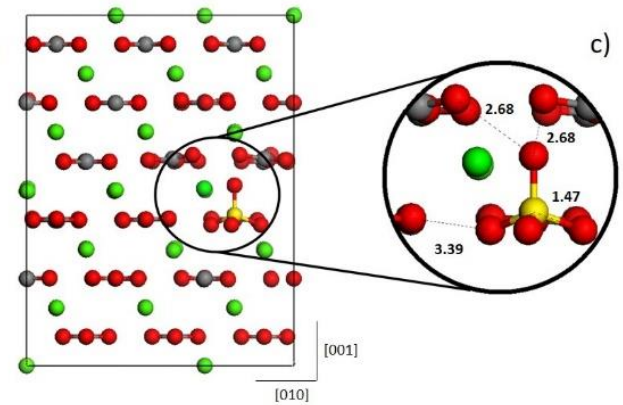

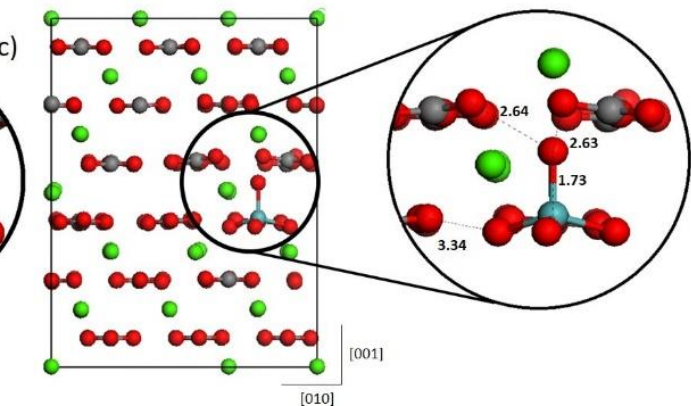

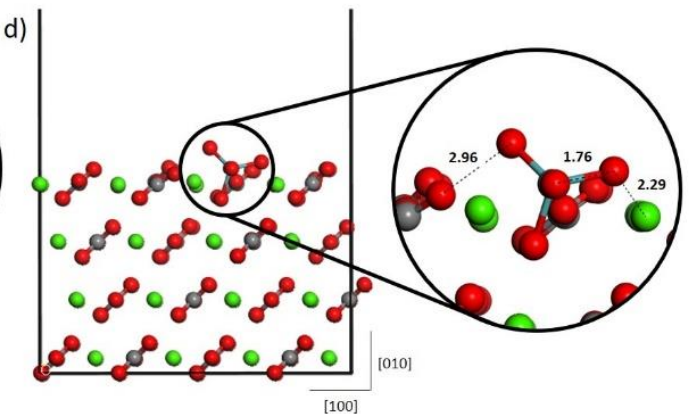

b)

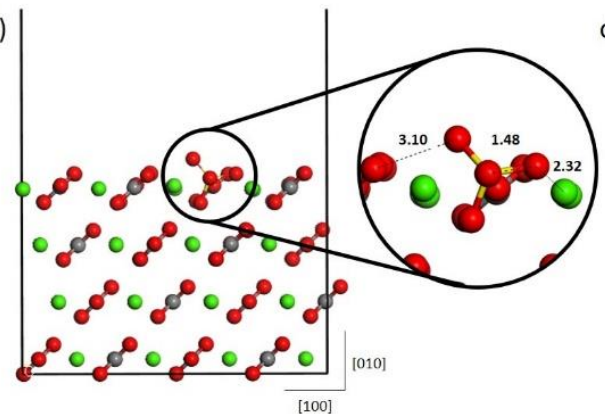

Figure 4. Comparison of the geometry of incorporation sulfate $(a, b)$ and molybdate $(c, d)$ anions in the bulk (a, c) and (10.4) surface (b, d) of calcite. Interatomic distances are represented in $\AA$.

\section{Conclusions}

We have presented a computer simulation study, based on density functional theory, of the incorporation of sulfate and molybdate impurities in calcium carbonates. The trend in incorporation stability of molybdate anions in anhydrous calcium carbonate phases is similar to the one obtained here, and in previous work, for sulfate anions (vaterite $>$ calcite $>$ aragonite). The $12 \mathrm{c}$ site of the $\mathrm{P}_{6} 5_{2} 2$ structure of vaterite is the most stable substitution site for both sulfate and molybdate anions. We have also included for the first time the hydrated phases as possible hosts for these ions, and we show that they exhibit $\left(\mathrm{XO}_{4}\right)^{2-} /\left(\mathrm{CO}_{3}\right)^{2-}$ exchange energies which are intermediate between those of calcite and aragonite. We found that there is a strong linear correlation between the exchange energies for molybdates and sulfates. While the correlation between the stability of a tetrahedral impurity and the density of the host is confirmed for the anhydrous phases, it cannot be extended to the hydrated phases which have much lower density. We demonstrate here that a measure of the space available in the site for substitution, in this case the shortest distance from impurity oxygen to carbonate oxygen, can be used instead to rationalize the order of stabilities of the impurities across all the phases, included the hydrated ones.

We have also obtained the solution energies as a measure of stability against the formation of a competing phase (calcium sulfate or calcium molybdate, respectively), and found that they are strongly positive, much more so for molybdate than for sulfate. This is consistent with the larger size 
of the molybdate ion, which makes it more difficult to accommodate a fourth oxygen atom at the host site. We estimated the maximum molar fraction that is thermodynamically stable against phase separation and found them to be negligible (below typical detection limits) in all cases except for sulfate in vaterite. Whilst some level of metastable lattice substitution is possible, based on the low impurity stability we conclude that other incorporation pathways, including surface substitution/adsorption or stabilization via defects or other impurities in the bulk, must account for most of the detected sulfate ions in carbonates. In the case of molybdate, this conclusion is even stronger, because the stability of the impurities with respect to phase separation is much lower. Preliminary calculations of sulfate and molybdate substitutions at a calcite surface (the (10.4) termination) indeed find that solution energies are $20-30 \%$ of the bulk values.

Our results suggest that the magnitude of incorporation of trace amounts of sulfur and molybdenum in speleothems is critically affected by factors like the crystallinity of the carbonate phases present. Because incorporation at the surface is much more favorable than in the bulk, it is likely that in samples with lower crystallinity (higher specific surface area), a higher concentration of traceelement impurity will be detected, regardless of the magnitude of the paleo-volcanic activity responsible for the atypical trace-element abundance at a particular time. Future investigations of the chemistry of sulfur and molybdenum incorporation into calcium carbonate speleothems should probably focus on surface and grain boundary incorporation rather than on lattice bulk substitutions. Computer simulations explicitly accounting for particle morphologies and solid/aqueous interfaces would be able to provide more quantitative predictions of the effect of crystallinity on the equilibrium partitioning of these impurities between the carbonate minerals and aqueous solution.

\section{Acknowledgements}

This work was supported by the Natural Environment Research Council through the SCENARIO DTP (grant ref NE/L002566/1), the Centre for Past Climate Change (CPCC) at the University of Reading; and ARCHER, the UK's national high-performance computing service, via the UK's HPC Materials Chemistry Consortium (EPSRC grant ref EP/R029431).

\section{References}

Affolter, S., Häuselmann, A., Fleitmann, D., Edwards, R.L., Cheng, H. and Leuenberger, M. (2019) Central Europe temperature constrained by speleothem fluid inclusion water isotopes over the past 14,000 years. Sci Adv 5, eaav3809.

Arroyo-de Dompablo, M.E., Fernández-González, M.A. and Fernández-Díaz, L. (2015) Computational investigation of the influence of tetrahedral oxoanions (sulfate, selenate and chromate) on the stability of calcium carbonate polymorphs. RSC Adv. 5, 59845-59852.

Badertscher, S., Borsato, A., Frisia, S., Cheng, H., Edwards, R.L., Tüysüz, O. and Fleitmann, D. (2014) Speleothems as sensitive recorders of volcanic eruptions - the Bronze Age Minoan eruption recorded in a stalagmite from Turkey. Earth and Planetary Science Letters 392, 58-66. 
Balan, E., Blanchard, M., Pinilla, C. and Lazzeri, M. (2014) First-principles modeling of sulfate incorporation and ${ }^{34} \mathrm{~S} /{ }^{32} \mathrm{~S}$ isotopic fractionation in different calcium carbonates. Chemical Geology 374-375, 84-91.

Blöchl, P.E. (1994) Projector augmented-wave method. Physical Review B 50, 17953-17979.

Böke, H., Göktürk, E.H., Caner-Saltık, E.N. and Demirci, Ş. (1999) Effect of airborne particle on $\mathrm{SO}_{2}-$ calcite reaction. Applied Surface Science 140, 70-82.

Busenberg, E. and Plummer, L.N. (1985) Kinetic and thermodynamic factors controlling the distribution of $\mathrm{SO}_{3}{ }^{2-}$ and $\mathrm{Na}^{+}$in calcites and selected aragonites. Geochimica et Cosmochimica Acta 49, 713-725.

De Choudens-Sanchez, V. and Gonzalez, L.A. (2009) Calcite and Aragonite Precipitation Under Controlled Instantaneous Supersaturation: Elucidating the Role of $\mathrm{CaCO}_{3}$ Saturation State and $\mathrm{Mg} / \mathrm{Ca}$ Ratio on Calcium Carbonate Polymorphism. Journal of Sedimentary Research 79, 363 376.

de Leeuw, N.H. and Parker, S.C. (1998) Surface Structure and Morphology of Calcium Carbonate Polymorphs Calcite, Aragonite, and Vaterite: An Atomistic Approach. The Journal of Physical Chemistry B 102, 2914-2922.

De Villiers, J.P.R. (1971) Crystal Structures of Aragonite, Strontianite, and Witherite. American Mineralogist 56, 758-767.

Dorale, J.A., Edwards, R.L., Calvin-Alexander Jr, E., Shen, C.C., Richards, D.A. and Cheng, H. (2004) Studies of Cave Sediments. Springer US, Boston, MA.

Fairchild, I.J. and Treble, P.C. (2009) Trace elements in speleothems as recorders of environmental change. Quaternary Science Reviews 28, 449-468.

Fernández-Díaz, L., Fernández-González, Á. and Prieto, M. (2010) The role of sulfate groups in controlling $\mathrm{CaCO}_{3}$ polymorphism. Geochimica et Cosmochimica Acta 74, 6064-6076.

Field, L.P., Milodowski, A.E., Shaw, R.P., Stevens, L.A., Hall, M.R., Kilpatrick, A., Gunn, J., Kemp, S.J. and Ellis, M.A. (2018) Unusual morphologies and the occurrence of pseudomorphs after ikaite $\left(\mathrm{CaCO}_{3} \cdot 6 \mathrm{H}_{2} \mathrm{O}\right)$ in fast growing, hyperalkaline speleothems. Mineralogical Magazine 81, 565-589.

Finch, A.A., Shaw, P.A., Weedon, G.P. and Holmgren, K. (2001) Trace element variation in speleothem aragonite: potential for palaeoenvironmental reconstruction. Earth and Planetary Science Letters 186, 255-267.

Fischbeck, R. and Müller, G. (1971) Monohydrocalcite, hydromagnesite, nesquehonite, dolomite, aragonite, and calcite in speleothems of the Fränkische Schweiz, Western Germany. Contributions to Mineralogy and Petrology 33, 87-92.

Fleitmann, D., Cheng, H., Badertscher, S., Edwards, R.L., Mudelsee, M., Göktürk, O.M., Fankhauser, A., Pickering, R., Raible, C.C., Matter, A., Kramers, J. and Tüysüz, O. (2009) Timing and climatic impact of Greenland interstadials recorded in stalagmites from northern Turkey. Geophysical Research Letters 36.

Given, R.K. and Wilkinson, B.H. (1985) Kinetic Control of Morphology, Composition, and Mineralogy of Abiotic Sedimentary Carbonates. SEPM Journal of Sedimentary Research Vol. 55, 109-119.

Hartland, A., Fairchild, I.J., Lead, J.R., Borsato, A., Baker, A., Frisia, S. and Baalousha, M. (2012) From soil to cave: Transport of trace metals by natural organic matter in karst dripwaters. Chemical Geology 304-305, 68-82.

Hesse, K.F., Küppers, H. and Suess, E. (1983) Refinement of the structure of Ikaite, $\mathrm{CaCO}_{3}-6 \mathrm{H}_{2} \mathrm{O}$, Zeitschrift für Kristallographie - Crystalline Materials, p. 227.

Kampschulte, A., Bruckschen, P. and Strauss, H. (2001) The sulphur isotopic composition of trace sulfates in Carboniferous brachiopods: implications for coeval seawater, correlation with other geochemical cycles and isotope stratigraphy. Chemical Geology 175, 149-173.

Kresse, G. and Furthmüller, J. (1996a) Efficiency of ab-initio total energy calculations for metals and semiconductors using a plane-wave basis set. Computational Materials Science 6, 15-50.

Kresse, G. and Furthmüller, J. (1996b) Efficient iterative schemes for ab initio total-energy calculations using a plane-wave basis set. Physical Review B 54, 11169-11186.

Kresse, G. and Joubert, D. (1999) From ultrasoft pseudopotentials to the projector augmented-wave method. Physical Review B 59, 1758-1775. 
Lacelle, D., Lauriol, B. and Clark, I.D. (2009) Formation of seasonal ice bodies and associated cryogenic carbonates in caverne de l'ours, Québec, Canada: Kinetic isotope effects and pseudobiogenic crystal structures. Journal of Cave and Karst Studies 71, 48-62.

Lowe, D.J. (2011) Tephrochronology and its application: A review. Quaternary Geochronology 6, 107153.

Malaga-Starzec, K., Panas, I. and Lindqvist, O. (2004) Model study of initial adsorption of $\mathrm{SO}_{2}$ on calcite and dolomite. Applied Surface Science 222, 82-88.

Markgraf, S. and Reeder, R. (1985) High-temperature structure refinements of calcite and magnesite. Am. Mineral. 70, 590-600.

Marshall, D., Ghaleb, B., Countess, R. and Gabities, J. (2009) Preliminary paleoclimate reconstruction based on a 12,500 year old speleothem from Vancouver Island, Canada: stable isotopes and UTh disequilibrium dating. Quaternary Science Reviews 28, 2507-2513.

McCarroll, D. and Loader, N.J. (2004) Stable isotopes in tree rings. Quaternary Science Reviews 23, 771-801.

Perdew, J.P., Burke, K. and Ernzerhof, M. (1996) Generalized Gradient Approximation Made Simple. Physical Review Letters 77, 3865-3868.

Railsback, L.B., Brook, G.A., Chen, J., Kalin, R. and Fleisher, C.J. (1994) Environmental Controls on the Petrology of a Late Holocene Speleothem from Botswana with Annual Layers of Aragonite and Calcite. SEPM Journal of Sedimentary Research Vol. 64A, 147-155.

Raiteri, P., Gale, J.D., Quigley, D. and Rodger, P.M. (2010) Derivation of an Accurate Force-Field for Simulating the Growth of Calcium Carbonate from Aqueous Solution: A New Model for the Calcite-Water Interface. The Journal of Physical Chemistry C 114, 5997-6010.

Robock, A. (2000) Volcanic eruptions and climate. Reviews of Geophysics 38, 191-219.

Rohl, A.L., Wright, K. and Gale, J.D. (2003) Evidence from surface phonons for the $(2 \times 1)$ reconstruction of the (1014) surface of calcite from computer simulation. American Mineralogist 88, 921-925.

Ruiz-Hernandez, S.E., Grau-Crespo, R., Ruiz-Salvador, A.R. and De Leeuw, N.H. (2010) Thermochemistry of strontium incorporation in aragonite from atomistic simulations. Geochimica et Cosmochimica Acta 74, 1320-1328.

Severi, M., Udisti, R., Becagli, S., Stenni, B. and Traversi, R. (2012) Volcanic synchronisation of the EPICA-DC and TALDICE ice cores for the last $42 \mathrm{kyr}$ BP. Climate of the Past 8, 509-517.

Sigl, M., McConnell, J.R., Layman, L., Maselli, O., McGwire, K., Pasteris, D., Dahl-Jensen, D., Steffensen, J.P., Vinther, B., Edwards, R., Mulvaney, R. and Kipfstuhl, S. (2013) A new bipolar ice core record of volcanism from WAIS Divide and NEEM and implications for climate forcing of the last 2000 years. Journal of Geophysical Research: Atmospheres 118, 1151-1169.

St Pierre, E., Zhao, J.-X. and Reed, E. (2009) Expanding the utility of Uranium-series dating of speleothems for archaeological and palaeontological applications. Journal of Archaeological Science 36, 1416-1423.

Stoffers, P. and Fischbeck, R. (1974) Monohydrocalcite in the sediments of Lake Kivu (East Africa). Sedimentology 21, 163-170.

Swainson, I.P. (2008) The structure of monohydrocalcite and the phase composition of the beachrock deposits of Lake Butler and Lake Fellmongery, South Australia. American Mineralogist 93, 1014-1018.

Ünal-İmer, E., Shulmeister, J., Zhao, J.-X., Tonguç Uysal, I., Feng, Y.-X., Duc Nguyen, A. and Yüce, G. (2015) An 80 kyr-long continuous speleothem record from Dim Cave, SW Turkey with paleoclimatic implications for the Eastern Mediterranean. Scientific reports 5, 13560-13560.

Vavouraki, A.I., Putnis, C.V., Putnis, A. and Koutsoukos, P.G. (2008) An Atomic Force Microscopy study of the growth of calcite in the presence of sodium sulfate. Chemical Geology 253, 243251.

Voelker, A.H.L. (2002) Global distribution of centennial-scale records for Marine Isotope Stage (MIS) 3: a database. Quaternary Science Reviews 21, 1185-1212.

Wang, J. and Becker, U. (2009) Structure and carbonate orientation of vaterite (CaCO3). American Mineralogist 94, 380-386. 
Wang, Q., Grau-Crespo, R. and de Leeuw, N.H. (2011) Mixing Thermodynamics of the CalciteStructured (Mn, $\mathrm{Ca}) \mathrm{CO}_{3}$ Solid Solution: A Computer Simulation Study. The Journal of Physical Chemistry B 115, 13854-13861.

Yalcin, K., Wake, C.P., Kreutz, K.J., Germani, M.S. and Whitlow, S.I. (2007) Ice core paleovolcanic records from the St. Elias Mountains, Yukon, Canada. Journal of Geophysical Research 112, D08102-D08102.

Zielinski, G.A. (2000) Use of paleo-records in determining variability within the volcanism-climate system. Quaternary Science Reviews 19, 417-438.

Zielinski, G.A., Mayewski, P.A., Meeker, L.D., Whitlow, S., Twickler, M.S., Morrison, M., Meese, D.A., Gow, A.J. and Alley, R.B. (1994) Record of Volcanism Since 7000 B.C. from the GISP2 Greenland Ice Core and Implications for the Volcano-Climate System. Science 264, 948-952. 


\section{Supplementary information}

a)

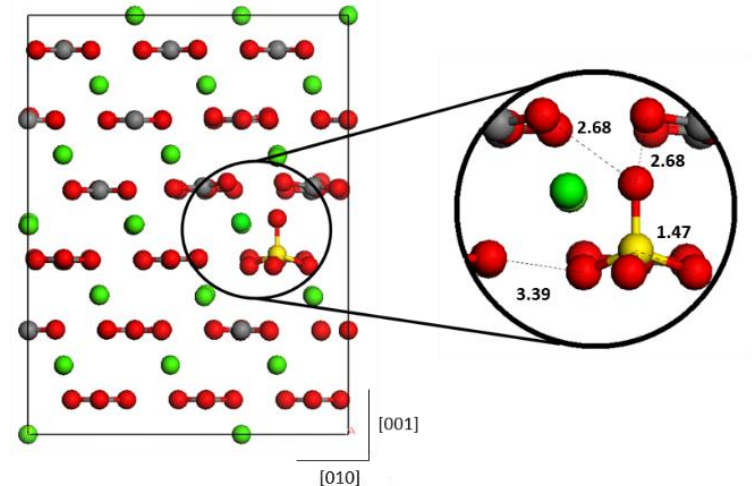

b)

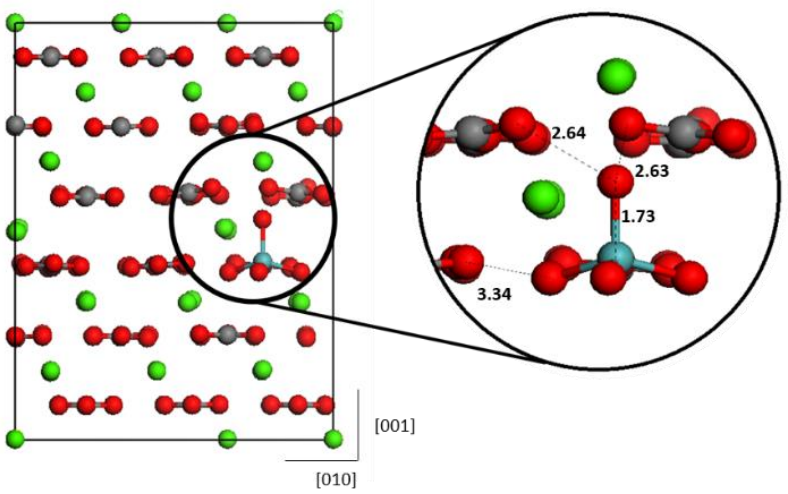

Figure S1. Optimized geometries for the incorporation of a) sulfate and b) molybdate oxyanions into the bulk of the calcite supercell. Here, X-O and O-O bond lengths represent distance in $\AA$.

a)

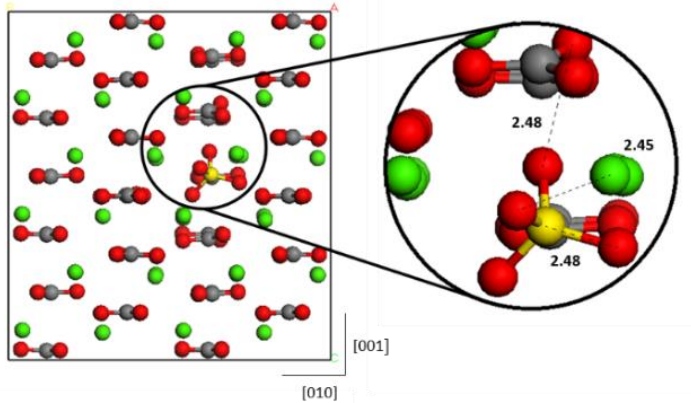

b)

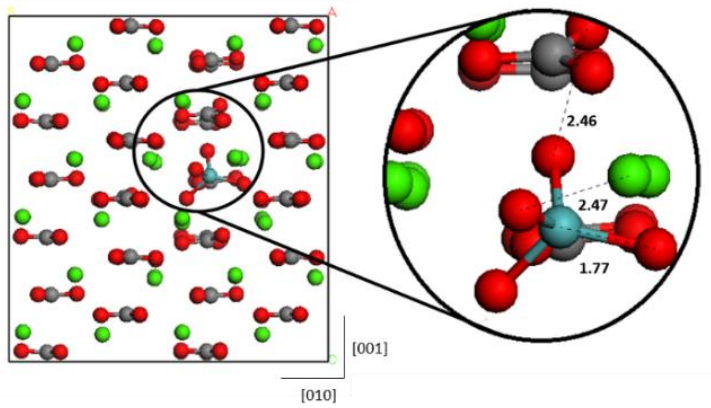


Figure S2. Optimized geometry for the incorporation of a) sulfate and b) molybdate oxyanions into the bulk of aragonite. Interatomic distances are represented in $\AA$.

a)

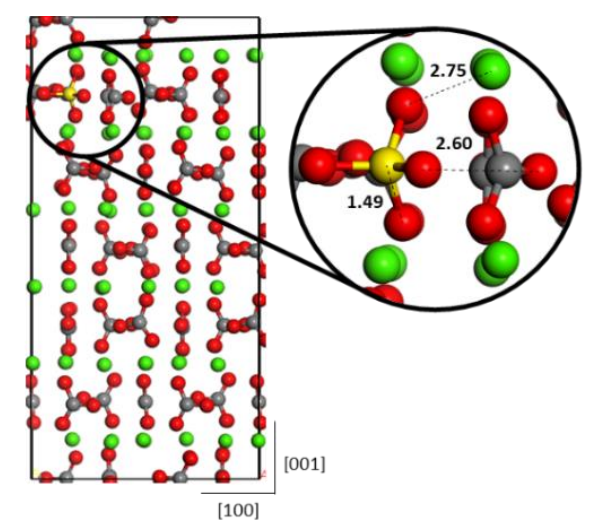

b)

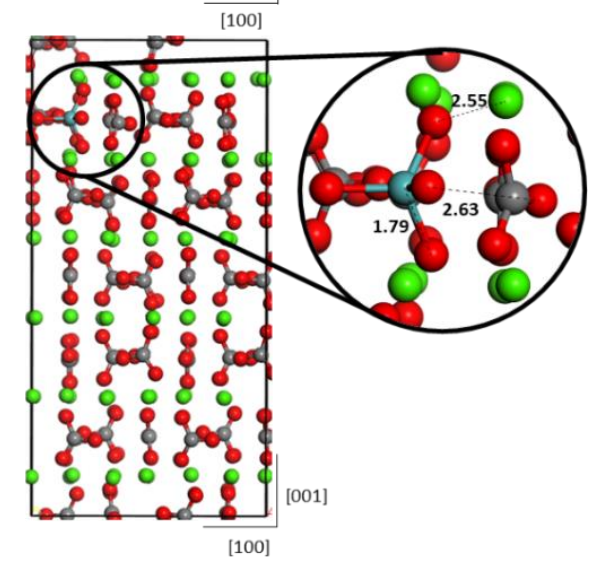

Figure S3. Optimized geometry following incorporation of a) sulfate and b) molybdate into the bulk of vaterite at the $12 \mathrm{c}$ carbonate sites. Interatomic distances shown are in $\AA$. 
a)

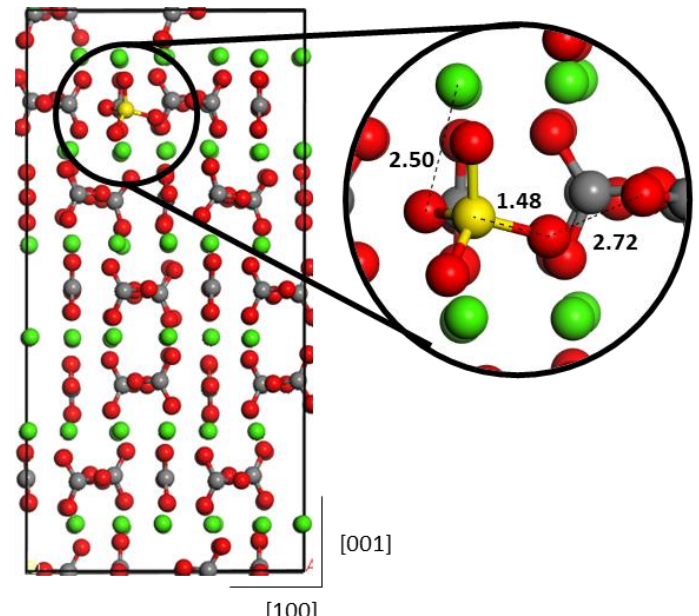

b)

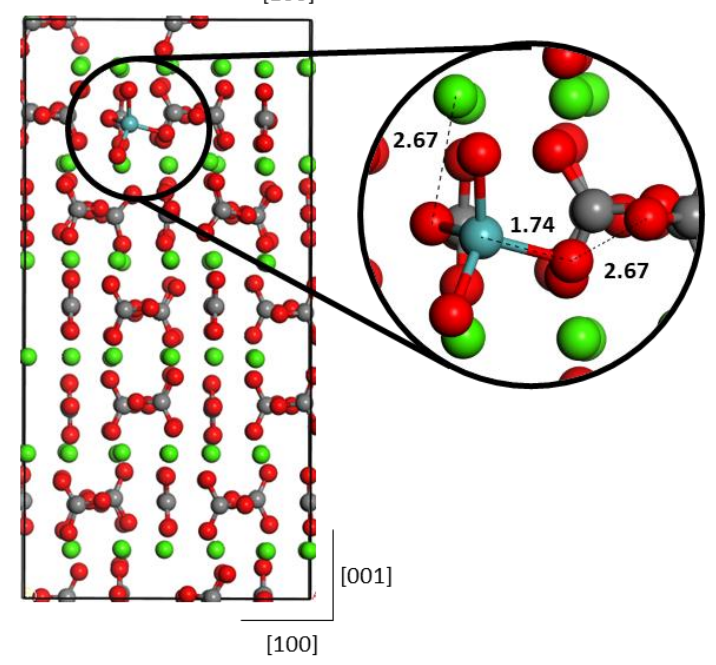

Figure S4. Optimized geometry for the incorporation of a) sulfate and b) molybdate into the bulk of vaterite at the 6 a carbonate sites. Interatomic distances shown are in $\AA$. 
a)

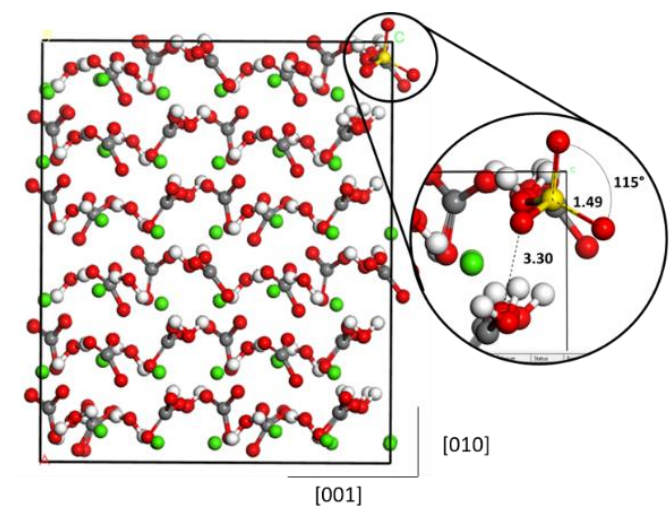

b)

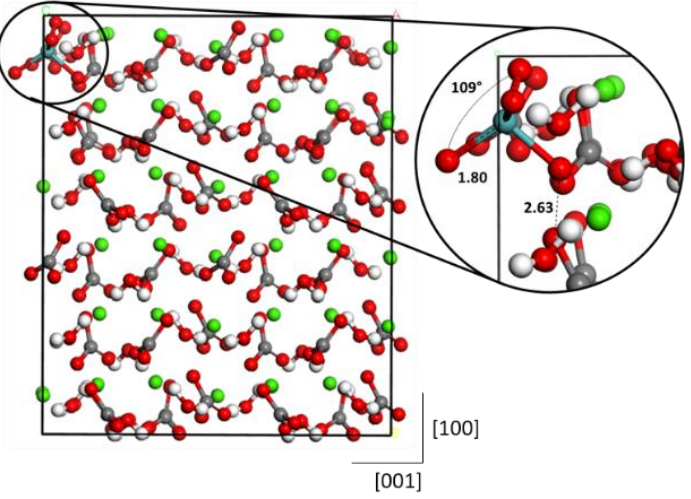

Figure S5. Optimized geometry following incorporation of a) sulfate and b) molybdate incorporation into $\mathrm{MHC}$ at carbonate site $3 \mathrm{a} 1$. Interatomic distances are shown in $\AA$.

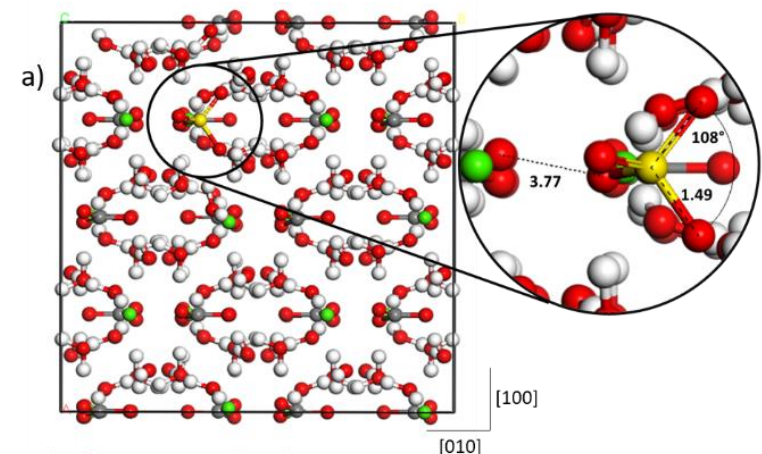

b)

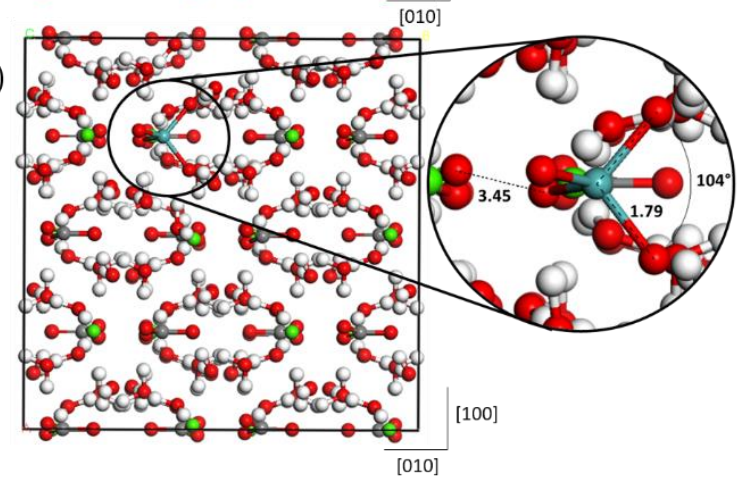

Figure S6. Optimized geometry following incorporation of a) sulfate and b) molybdate incorporation into the bulk of ikaite. Interatomic distances are shown in $\AA$. 